\title{
Understanding Fate and Effects of Copper Pesticides in Aquatic Systems
}

\author{
Ben E. Willis, West M. Bishop \\ SePRO Research and Technology Campus, SePRO Corporation, Whitakers, NC, USA \\ Email: ben.willis@sepro.com
}

Received 31 March 2016; accepted 3 May 2016; published 6 May 2016

Copyright (C) 2016 by authors and Scientific Research Publishing Inc.

This work is licensed under the Creative Commons Attribution International License (CC BY).

http://creativecommons.org/licenses/by/4.0/

(c) (i) Open Access

\begin{abstract}
Copper sulfate and other chelated or complex copper forms are commonly used to manage nuisance and noxious algae and invasive weeds through direct application to aquatic systems. Regulatory scrutiny and perceived non-target species impacts supported the need for an accurate risk assessment of fate and effects of copper applied as a pesticide. Copper inputs to aquatic systems originate from numerous sources (e.g. natural, storm water, industrial) whereas direct pesticide applications account for approximately $13 \%$. Following a pesticide application, copper rapidly partitions to suspended algae and particulates and the majority $(>90 \%)$ of applied copper is transferred to sediments within 2 days. Copper subsequently shifts to less bioavailable forms and risks to non-target species are significantly decreased. Additionally, the copper that partitions to sediments is diluted through migration to greater sediments depths and accretion. Even when elevated sediment copper concentrations were measured following chronic applications or high treatment levels, no adverse effects to non-target species were observed with laboratory or field experiments. When used appropriately copper can be an effective tool for water resource managers with negligible environmental impact.
\end{abstract}

\section{Keywords}

Sediments, Risks, Bioavailability, Algaecide, Herbicide, Copper

\section{Introduction}

Copper, as copper sulfate and other chelated or complexed forms are effective pesticides for use in agriculture and direct application to aquatic systems with no toxicity concerns to humans when used according to label directions [1]. From control of fungi in citrus, potentially toxic algae (cyanobacteria) in drinking water to nuisance aquatic weeds in flood and irrigation canals, copper-based pesticides are among the oldest and most widely used pest management solutions [2]-[4]. The use of copper to control algae in water dates back more than a century [5] 
[6]. However, scrutiny regarding the use of copper has commanded investigations regarding the fate and potential impacts of copper applied as aquatic pesticides. The overall purpose of this analysis is to concisely summarize the fate and effects of copper from aquatic applications. Specifically, we address sources, fate, accumulation, and risks of copper in sediments of aquatic systems. Information regarding the ultimate fate and effects of copper can assist water resource managers and regulatory agencies in making informed decisions regarding copper use.

\section{Copper Sources}

Copper is commonly found in aquatic ecosystems at 0.2 to $30 \mu \mathrm{g} / \mathrm{L}$ in the water column, though usually $<5 \mu \mathrm{g} / \mathrm{L}$, and at $0.8-50 \mathrm{mg} / \mathrm{kg}$ in bottom sediments from undisturbed areas [3] [7]. There are a variety of anthropogenic and natural inputs of copper to freshwater systems. Mobilization of weathered and disturbed soils contributes $68 \%$ of the copper load to water bodies [8] unless an industrial source is present [9]. Industrial sources of copper include: wood production, iron and steel production, waste incineration, industrial applications, coal combustion, nonferrous metal mining, oil and gasoline combustion, and phosphate fertilizer manufacture. According to the Toxics Release Inventory documents [10], total industrial releases of copper in the U.S. during 2001 were approximately 5050 metric tons (11.1 million pounds), though only $0.4 \%$ of the total was released into water. Stormwater runoff can be a substantial source of copper in aquatic systems with concentrations between 1 and $100 \mu \mathrm{g} \mathrm{Cu} / \mathrm{L}$ commonly measured [8]. Copper in storm water runoff originates from buildings, automobiles (e.g. brakes, engine, tires), and wet and dry depositional processes [11]-[13]. Sources of natural atmospheric deposition of copper include: windblown soils, forest fires, volcanoes, biogenic processes, and sea spray [14]. Domestic waste water can commonly be the major anthropogenic source of copper in waterways [15] [16]. Copper can enter surface waters as a result of agricultural runoff and domestic fertilizer use. Loading rates of copper into surface water from irrigation water runoff has been measured from 0.307 to $8.34 \mathrm{mg} / \mathrm{hour}$, depending time period and rainfall [17]. The amount of elemental copper applied to U.S. water bodies for aquatic weed and algae control is estimated at 4082 - 4989 metric tons ( 9 - 11 million pounds) as copper sulfate pentahydrate and 136 metric tons (300,000 pounds) as chelated copper varieties [1]. Aquatic copper products primarily include copper sulfate based inorganic chemistries and copper bound to organic chelating agents that are designed to increase the stability and efficacy of the copper ion [18]-[20]. Chelating agents are commonly comprised of ethanolamine complexes in algaecide formulations (e.g. Captain ${ }^{\circledR}, \mathrm{K}_{-} \mathrm{Tea}{ }^{\circledR}$ ) and/or ethylenediamine complexes as prevalent in herbicides (e.g. Komeen ${ }^{\circledR}$, Nautique ${ }^{\circledR}$ ). The proportional copper loading attributed to algaecide and herbicide use in aquatic systems is approximately $13 \%$ relative to amount of copper from natural deposition, industrial sources, and urban runoff [21].

\subsection{Copper Fate from Aquatic Pesticide Applications}

Following an algaecide treatment, applied copper moves from the water column to algae and ultimately to bottom sediments in an aquatic system [22]. The transport of copper to sediments is mediated by sorption to suspended particulates and precipitation via interaction with carbonate and sulfide [3]. Liu et al. [23] measured rapid and strongly bound copper sorption to suspended sediment particles within 2 hours after copper applications with 99\% of applied copper transferring to bottom sediments in 2 days. Movement of copper as an algaecide to sediments is intensely facilitated by algae biomass. Copper algaecides rapidly sorb ( 15 minutes) to numerous binding sites (carboxylic, sulfhydryl, phosphate groups, transport proteins, etc.) on algae [24], and the movement of copper applied as an algaecide has been monitored with settling algae following treatment [25]. This is consistent with Jones et al. [26] finding the majority of copper binding in treated sediments short term after application was associated with the oxidizable fraction comprised primarily of algae biomass. Therefore, movement of copper out of a water resource treated with a copper pesticide is strongly dependent on the settling of algae and other suspended solids.

Copper from an algaecide or herbicide treatment is not expected to be measurable in bottom sediments where the application method only treats a portion of the water body (e.g. band treatments), due to dilution and lateral copper movement. A study by Iwinski et al. [27] comparing coves treated $\sim 5$ times a year for up to 10 years indicated that a majority of the sites had similar copper concentrations as adjacent untreated coves $(p=0.77, \alpha=$ 0.05 ; treated $\mathrm{n}=27$, mean $=51.6 \mathrm{mg} \mathrm{Cu} / \mathrm{kg}$; untreated $\mathrm{n}=27$, mean $=151.3 \mathrm{mg} \mathrm{Cu} / \mathrm{kg}$ ). In circumstances of repeated or large treatment areas (e.g. whole water column treatment), copper from an application could poten- 
tially increase sediment copper concentration [28]. The increase of sediment copper concentration after an application, has been measured to range from 0.9 - $12 \mathrm{mg} \mathrm{Cu} / \mathrm{kg}$ [28] [29], respectively. The approximate tenfold increase between these two measured concentrations is hypothesized as a result of bioturbation and sediment accretion. For instance, the $0.9 \mathrm{mg} \mathrm{Cu} / \mathrm{kg}$ was interpolated from the measured increase of sediment copper concentrations over three years with multiple applications in an aquaculture pond. While, the $12 \mathrm{mg} \mathrm{Cu} / \mathrm{kg}$ was measured in the top $3 \mathrm{~cm}$ of sediment $(6 \mathrm{mg} \mathrm{Cu} / \mathrm{kg}$ in the top $8 \mathrm{~cm}$ ) in a similar sized aquaculture pond soon after applied copper partitioned to the bottom sediments ( 2 - 3 weeks after treatment). This demonstrates copper is significantly diluted through time, which is likely attributed to accretion and copper migration to greater sediment depths. Liu et al. [23] measured copper to migrate up to $14-16 \mathrm{~cm}$ over a 12 week period thereby diluting the concentration. According to Jacinthe et al. [30], the sediment copper concentration in three different central Indiana reservoirs increased by approximately 3 - $4 \mathrm{mg} \mathrm{Cu} / \mathrm{kg}$ per algaecide application applied throughout four consecutive years of treatments. Hullebusch et al. [31] measured an increase of $7.7 \mathrm{mg} \mathrm{Cu} / \mathrm{kg}$ following a copper sulfate application of $0.197 \mathrm{mg} / \mathrm{L}$ in a French reservoir with a 1.2 meter average depth. Overall, the expected increase of sediment copper concentration based on reported copper concentrations following applications is expected to be $<8 \mathrm{mg} \mathrm{Cu} / \mathrm{kg}$ per application. However, this accumulation is lessened through time due to downward migration and sediment accretion.

\subsection{Copper Bioavailability and Non-Target Risks}

Copper that partitions to sediments following a pesticide application is transformed to more stable forms through time, such as malachite and chalcocite [23]. Jones et al. [26] found that the bioavailability of sediment-sorbed copper continues to transform to more stable and biologically unreactive forms following transport to sediments, which further decreases risks to biota. The sediment copper concentration that may cause adverse effects to non-target organisms can differ widely (orders of magnitude) depending on sediment characteristics [28] [32]. Acid volatile sulfides [33], $\mathrm{pH}$ [34], cation exchange capacity [35], and organic matter content and type [36] [37] are important sediment characteristics that influence copper bioavailability in sediments. In context, a sandy and oxic sediment with low organic matter is expected to have the greatest fraction of bioavailable copper, while an anoxic high organic matter sediment primarily composed of fine particles (silt and clay) would have the least bioavailable fraction of copper. Overall, copper is a common constituent of the earth's crust, with an ultimate fate in sediments and soils as relatively unreactive and thermodynamically stable forms.

Two common methods for screening sediments for copper toxicity are the acid volatile sulfides and simultaneously extracted metals ratio (AVS: SEM) and sediment quality guidelines [38]. The AVS:SEM technique is based on the amount of sulfides released from sediments simultaneously with metals using a $1 \mathrm{~N} \mathrm{HCl} \mathrm{[39],} \mathrm{and} \mathrm{a}$ ratio greater than one indicates lack of toxicity [40]. However, this technique is limited to predicting the lack of toxicity, not presence, because AVS is not the only phase which copper partitions [38]. Values exist for screening sediments based on copper concentrations (NOAA Screening Quick Reference Tables) [41], although these values predict potential for adverse effects and are likely conservative guidelines [22], as well as lack site specificity [42]. Laboratory toxicity experiments have been used to measure the bioavailability of copper in sediments, and subsequently used to predict risks of copper in site specific sediments [22] [28] [32]. The bioavailability of copper is critical to assess as copper concentrations alone are often insufficient to accurately predict risks to in situ biota [35]. Laboratory experiments with site sediment amended with copper are considered to represent worst-case scenarios because there are no additional inputs of water or sediment and typically have a short acclimation period; these can reduce the bioavailability and risks of copper in sediments in the field [43].

Overall, studies have demonstrated that sediments, from water bodies treated with copper, collected relatively shortly after treatment, as well as after years of copper pesticide treatments have not produced measurable adverse effects to sensitive sentinel species [22] [27]-[29] [32]. Specifically, Han et al. [29] found sediments from aquaculture ponds treated periodically for a series of years with copper sulfate to not elicit adverse effects to Hyalella azteca (amphipod) or Typha latifolia (common cattail). Huggett et al. [32] found the copper concentrations in sediments from a lake frequently treated with copper sulfate to control algae (Steilacoom Lake, WA, U.S.A.) were insufficient to elicit adverse effects to Hyalella azteca (amphipod), Chironomus tentans (infaunal midge), and Ceriodaphnia dubia (water flea). Gallagher et al. [22] found sediments from Lake Murray, SC, U.S.A., in areas annually treated with a chelated copper herbicide, did not produce adverse effects to Hyalella azteca or Ceriodaphnia dubia. Willis [28] found the copper bioavailability in sediments from an aquaculture 
pond collected three weeks following a chelated copper algaecide application was inadequate to elicit adverse effects to Hyalella azteca. Iwinski et al. [27] found that coves in a lake treated $\sim 5$ times a year for up to 10 years lacked measurable adverse effects based on laboratory toxicity experiments and in situ benthic abundance data.

\section{Future Research}

Future research will continue to focus on understanding the bioavailability of copper to non-target species following application to aquatic systems. Short-term copper sorption kinetics will be assessed in terms copper formulation affinity and introduction to toxic sites of action in/on the target pest. The subsequent shift of copper available in an exposure (e.g. concentration, duration) to non-target organisms will concomitantly be measured. Operational evaluations will investigate strategic use patterns of copper products and specifically calculate the most effective formulation to achieve desired results with lowest amounts of copper applied [44]. Furthermore, research will build on site specific fate assessments of copper in a variety of field sites in order to provide data on the weight of evidence approach in risk assessment.

\section{Summary}

Copper is a naturally prevalent element, essential micronutrient, and critical component of many anthropogenic activities. Copper inputs to aquatic systems originate from numerous sources (e.g. natural, storm water, industrial) whereas pesticides account for a relatively small proportion. Following a pesticide application, the ultimate fate of copper is transfer to sediments where migration and accretion can occur. In sediments, copper is bound in less bioavailable forms therefore decreasing risks to non-target species. Aquatic copper algaecide and herbicide use patterns, application rates and dissipation profiles have been intensely studied and are well documented [45]. These studies are the basis for copper product labels, as approved by USEPA Office of Pesticide Programs, to prevent unreasonable risks to humans and other non-target species. USEPA [1] recently approved continued use of copper in aquatic environments factoring in application rate, frequency and environmental risk. This information is reflected in USEPA registered copper pesticide labels to ensure no unreasonable adverse impacts. With stewardship of these copper algaecides and herbicides, management of nuisance and noxious algae and aquatic weed infestations with copper can continue to be an effective and environmentally sound solution.

\section{Acknowledgements}

The authors thank Shaun Hyde, Dr. Tyler Koschnick and Dr. Mark Heilman for their helpful comments and support of this risk assessment.

\section{References}

[1] United States Environmental Protection Agency (2009) Reregistration Eligibility Decision for Coppers. 738-R-09-304. $176 \mathrm{p}$.

[2] Clark, J. (1902) On the Toxic Properties of Some Copper Compounds with Special Reference to Bordeaux Mixture. Botanical Gazette, 33, 26-48. http://dx.doi.org/10.1086/328192

[3] Flemming, C.A. and Trevors, J.T. (1989) Copper Toxicity and Chemistry in the Environment: A Review. Water, Air, Soil \& Pollution, 44, 143-158. http://dx.doi.org/10.1007/BF00228784

[4] United States Environmental Protection Agency (2014) Cyanobacteria and Cyanotoxins: Information for Drinking Water Systems. EPA-810F11001.

[5] Moore, G.T. and Kellerman, K.F. (1905) Copper as an Algicide and Disinfectant in Water Supplies. Bulletin of the Bureau of Plant Industry USDA, 76, 19-55.

[6] Murphy, K.J. and Barrett, P.R.F. (1993) Chemical Control of Aquatic Weeds, In: Pieterse, A.H. and Murphy, K.J., Eds., The Ecology and Management of Nuisance Aquatic Vegetation, Oxford Science, Oxford, 136-173.

[7] United States Environmental Protection Agency. (1984) Ambient water quality criteria for copper. 440/5/84/031 EPA (2007). 40 CFR Parts 141 and 142. Washington DC, 150 p.

[8] Georgopoulos, A.R., Yonone-Lioy, M.J., Opiekun, R.E. and Loiy, P.J. (2001) Environmental Copper: Its Dynamics and Human Exposure Issues. Journal of Toxicology of Environmental Health Part B, 4, 341-394. http://dx.doi.org/10.1080/109374001753146207 
[9] Nolte, J. (1988) Pollution Source Analysis of River Water and Sewage Sludge. Environmental and Technology Letters, 9, 857-868. http://dx.doi.org/10.1080/09593338809384642

[10] Agency for Toxic Substances and Disease Registry (2004) Toxicological Profile for Copper. U.S. Department of Health and Human Services, Public Health Service, Atlanta, GA.

[11] Sansalone, J.J. and Buchberger, S.G. (1997) Partitioning and First Flush of Metals in Urban Roadway Storm Water. Journal Environmental Engineering, 123, 134-143. http://dx.doi.org/10.1061/(ASCE)0733-9372(1997)123:2(134)

[12] Ball, J.E., Jenks, R. and Aubourg, D. (1998) An Assessment of the Availability of Pollutant Constituents on Road Surfaces. Science of the Total Environment, 209, 243-254. http://dx.doi.org/10.1016/S0048-9697(98)80115-0

[13] Davis, A.P. and Shokouhian, M.N.S. (2001) Loading Estimates of Lead, Copper, Cadmium, and Zinc in Urban Runoff from specific sources. Chemosphere, 44, 997-1009. http://dx.doi.org/10.1016/S0045-6535(00)00561-0

[14] World Health Organization (1998) Copper. Geneva: International Programme on Chemical Safety. United Nations Environment Programme, Interational Labour Organization, and World Health Organization. Environmental Health Criteria 200.

[15] Nriagu, J.O. and Pacyna, J.M. (1988) Quantitative Assessment of Worldwide Contamination of Air, Water and Soil by Trace Metals. Nature, 333, 134-139. http://dx.doi.org/10.1038/333134a0

[16] Isaac, R.A., Gil, L., Cooperman, A.N., Hulme, B.E., Ruiz, M., Jacobson, Larson, C. and Pancorbo, O.C. (1997) Corrosion in Drinking Water Distribution Systems: A Major Contributor of Copper and Lead to Wastewaters and Effluents. Environmental Science and Technology, 31, 3198-3203. http://dx.doi.org/10.1021/es970185i

[17] Kilbride, K.M., Paveglio, F.L., Altstatt, A.L., Henry, W.G. and Janik, C.A. (1998) Contaminant Loading in Drainage and Fresh Water Used for Wetland Management at Stillwater National Wildlife Refuge. Archives of Environmental Contamination and Toxicology, 35, 236-248. http://dx.doi.org/10.1007/s002449900372

[18] Straus, D.L. and Tucker, C.S. (1993) Acute Toxicity of Copper Sulfate and Chelated Copper to Channel Catfish Ictalarus punctatus. Journal of the World Aquaculture Society, 24, 390-395. http://dx.doi.org/10.1111/j.1749-7345.1993.tb00170.x

[19] Mastin, B.J. and Rodgers Jr., J.H. (2000) Toxicity and Bioavailability of Copper Herbicides (Clearigate, Cutrine Plus, and Copper Sulfate) to Freshwater Animals. Archives of Environmental Contamination and Toxicology, 39, 445-451. http://dx.doi.org/10.1007/s002440010126

[20] Bishop, W.M. and Rodgers Jr., J.H. (2012) Responses of Lyngbyawollei to Exposures of Copper-Based Algaecides: The Critical Burden Concept. Archives of Environmental Contamination and Toxicology, 62, 403-410. http://dx.doi.org/10.1007/s00244-011-9711-x

[21] Perwak, J., Bysshe, S., Goyer, M., Nelken, L., Scow, K., Walker, P. Wallace, D., Little, A. and Delos, C. (1980) An Exposure and Risk Assessment for Copper. EPA-440/4-81-015, Washington DC, 169 p.

[22] Gallagher, J., Duke, B. and Rodgers Jr., J.H. (2005) Responses of Hyalella azteca and Ceriodaphnia dubia to Reservoir Sediments Following Chelated Copper Herbicide Applications. Journal of Aquatic Plant Management, 43, 95-99.

[23] Liu, R., Zhao, D. and Barnett, M. (2006) Fate and Transport of Copper Applied in Channel Catfish Ponds. Water, Air, Soil \& Pollution, 176, 139-162. http://dx.doi.org/10.1007/s11270-006-9155-5

[24] Crist, R.H., Martin, J.R., Guptill, P.W., Eslinger, J.M. and Crist, D.R. (1990) Interaction of Metals and Protons with Algae. 2. Ion Exchange in Adsorption and Metal Displacement by Protons. Environmental Science and Technology, 24, 337-342. http://dx.doi.org/10.1021/es00073a008

[25] Button, K.S., Hostetter, H.P. and Mair, D.M. (1977) Copper Dispersal in a Water-Supply Reservoir. Water Research, 11, 539-544. http://dx.doi.org/10.1016/0043-1354(77)90161-0

[26] Jones, R., Hassan, S. and Rodgers, J. (2008) Influence of Contact Duration on Sediment Associated Copper Fractionation and Bioavailability. Ecotoxicology and Environmental Safety, 71, 104-116. http://dx.doi.org/10.1016/j.ecoenv.2007.09.004

[27] Iwinski, K.J., McQueen, A.D., Kinley, C.M., Calomeni, A.J., Geer, T.D. and Rodgers Jr., J.H. (2016) Sediment Copper Concentrations, in Situ Benthic Invertebrate Abundance, and Sediment Toxicity: Comparison f Treated and Untreated coves in a Southern Reservoir. Water, Air, \& Soil Pollution, 227, 85. http://dx.doi.org/10.1007/s11270-016-2778-2

[28] Willis, B.E. (2012) Detecting Copper Residues in Sediments from Aquatic Copper-Based Pesticide Applications. M.S. Thesis, Clemson University, Clemson.

[29] Han, F.X., Hargreaves, J.A., Knigery, W.L., Huggett, D.B. and Schlenk, D.K. (2001) Accumulation, Distribution, and Toxicity of Copper in Sediments of Catfish Ponds Receiving Periodic Copper Sulfate Applications. Journal of Environmental Quality, 30, 912-919. http://dx.doi.org/10.2134/jeq2001.303912x

[30] Jacinthe, P., Filippelli, G.M., Tedesco, L.P. and Licht, K.J. (2010) Distribution of Copper in Sediments from Fluvial Reservoirs Treated with Copper Triethanolamine Complex Algicide. Water, Air, \& Soil Pollution, 211, 35-48. http://dx.doi.org/10.1007/s11270-009-0278-3 
[31] Hullenbush, E., Chatenet, P., Delechat, V., Chazal, P., Froissard, D., Botineau, M., Ghestem, A. and Baudu, M. (2003) Copper Accumulated in Reservoir Ecosystem Following Copper Sulfate Treatment (St. Germian Les Belles, France). Water, Air, \& Soil Pollution, 150, 3-22. http://dx.doi.org/10.1023/A:1026148914108

[32] Huggett, D.B., Gillespie, W.B. and Rodgers Jr., J.H. (1999) Copper Bioavailability in Steilacoom Lake Sediments. Archives of Environmental Contamination and Toxicology, 36, 120-123. http://dx.doi.org/10.1007/s002449900450

[33] Di Toro, D.M., Mahony, J.J., Hansen, D.J., Scott, K.J., Hicks, M.B., Mayr, S.M. and Redmend, M.S. (1990) Toxicity of Cadmium in Sediments: The Role of Acid Volatile Sulfide. Environmental Toxicology and Chemistry, 9, 1487-1502. http://dx.doi.org/10.1002/etc.5620091208

[34] Burton, G.A. (1991) Assessing the Toxicity of Freshwater Sediments. Environmental Toxicology and Chemistry, 10, 1585-1627. http://dx.doi.org/10.1002/etc.5620101204

[35] Chapman, P.M., Wang, F.Y., Adams, W.J. and Green, A. (1998) Appropriate Applications of Sediment Quality Values for Metals and Metalloids. Environmental Science and Technology, 33, 3937-3941. http://dx.doi.org/10.1021/es990083n

[36] Besser, J.M., Brumbaugh, W.G., May, T.W. and Ingersoll, C.G. (2003) Effects of Organic Amendments on the Toxicity and Bioavailability of Cadium and Copper in Spiked Formulated Sediments. Environmental Toxicology and Chemistry, 22, 805-815. http://dx.doi.org/10.1002/etc.5620220419

[37] Milani, D., Reynoldson, T.B., Borgmann, U. and Kolasa, J.K. (2003) The Relative Sensitivity of Four Benthic Invertebrates to Metal Spiked-Sediment Exposures and Application to Contaminated Field Sediment. Environmental Toxicology and Chemistry, 22, 845-854. http://dx.doi.org/10.1002/etc.5620220424

[38] Ankley, G.T., Mattson, V.R., Leonard, E.N., West, C.W. and Bennett, J.L. (1993) Predicting the Acute Toxicity of Copper in Freshwater Sediments: Evaluation of the Role of Acid-Volatile Sulfide. Environmental Toxicology and Chemistry, 12, 315-320. http://dx.doi.org/10.1002/etc.5620120214

[39] Leonard, E.N., Cotter, A.M. and Ankley, G.T. (1996) Modified Diffusion Method for Analysis of Acid Volatile Sulfides and Simultaneously Extracted Metals in Freshwater Sediments. Environmental Toxicology and Chemistry, 15, 1479-1481. http://dx.doi.org/10.1002/etc.5620150908

[40] United States Environmental Protection Agency (2005) Procedures for Derivation of Equilibrium Partitioning Sediment Benchmarks (ESBs) for Protection of Benthic Organisms: Metal Mixtures (Cadmium, Copper, Lead, Nickel, Silver, and Zinc). EPA-600-R-02-011, Washington DC.

[41] Buchman, M.F. (2008) NOAA Screening Quick Reference Tables. NOAA OR\&R Report 08-1.

[42] Willis, B.E., Alley, B.L. and Rodgers Jr., J.H. (2013) Bioavailability and Analytical Measurement of Copper Residuals in Sediments. Water, Air, Soil \& Pollution, 224, 1423. http://dx.doi.org/10.1007/s11270-012-1423-y

[43] Gardham, S., Hose, G.C., Simpson, S.L., Jarolimek, C. and Chariton, A.A. (2014) Long-Term Copper Partitioning of Metal-Spiked Sediments Used in Outdoor Mesocosms. Environmental Science and Pollution Research, 21, 7130-7139. http://dx.doi.org/10.1007/s11356-014-2631-3

[44] Bishop, W.M., Willis, B.E. and Horton, C.T. (2015) Affinity and Efficacy of Copper Following an Algicide Exposure: Application of the Critical Burden Concept for Lyngbya wollei Control in Lay Lake, AL. Environmental Management, 55, 983-990. http://dx.doi.org/10.1007/s00267-014-0433-5

[45] United States Environmental Protection Agency (2016) Control and Treatment. http://www.epa.gov/nutrient-policy-data/control-and-treatment 